\author{
$\Theta(0 \Theta$ \\ Jurnal Terapan Manajemen dan Bisnis is licensed under \\ A Creative Commons Attribution-Non_Commercial 4.0 International License.
}

\title{
MAKING OF BOHEMIAN SKY DECORATION (FRINGE BOHEMIAN)
}

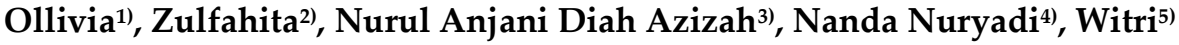 \\ 1) Mts. YPPU karimunting, Singkawang, Indonesia \\ E-mail: olivevia39@gmail.com \\ 2) STKIP Singkawang, Singkawang, Indonesia \\ E-mail: zulfahita@yahoo.co.id \\ 3) STKIP Singkawang, Singkawang, Indonesia \\ Email: nurulanjani434@gmail.com \\ 4) STKIP Singkawang, Singkawang, Indonesia \\ E-mail: nuryadinanda1@gmail.com, \\ 5) STKIP Singkawang, Singkawang, Indonesia \\ E-mail: witriwitri322@gmail.com
}

\begin{abstract}
For the student creativity program in this entrepreneurship class, we run a business program for hanging ornaments made of rope. We give this business the name of Making a Bohemian Ceiling Decoration (Fringe Bohemian). This Bohemian Ceiling Decoration is a craft made from rope. The rope used can be various as desired, such as rope, wool rope, plastic rope, etc. But we are here using the basic material of wool rope. This handicraft business aims to increase creativity and be innovative in entrepreneurship, especially for young entrepreneurs. The hanging decoration business from this rope is easy in the manufacturing process but it takes time and requires patience in making it and the materials needed to make this decoration easy to get. The form of our business is still in an individual stage only. We do not yet have official permission from the government, because this business is still new and is still trying to enter the business world. In the future, if this business can get extraordinary profits and have enough customers, then we will increase this business to be even bigger. Many factors need to be considered in order to advance this Bohemian Ceiling Decoration business. Important factors that must be considered in order to advance this business include choosing the right location, a good marketing strategy and determining affordable prices in the community. If all the factors above can be planned properly, it will be able to make this business grow well. For this reason, it is necessary to make a business plan as a reference in accelerating the business of making Bohemian Ceiling Decorations (Bohemian Fringe).
\end{abstract}

Keywords: Decoration; Bohemian Fringe; Business.

\section{Introduction}

A person's creativity has no limits. Creativity is an ability and an effective effort to create something that will be new or different from others (Herlina: 2003). Currently, there have been many business advances by relying on our creativity, whether it be in the culinary, fashion, and so on. Decoration is an item or object that aims to beautify an object (Suparta: 
2010). This hanging decoration that we will create is a form of creativity by utilizing the basic material, namely rope. This decoration can also be made yourself because the manufacturing process has a low level of difficulty depending on how creative we are in making it. This Bohemian (Fringe Boho) Ceiling Decoration is perfect for decorating the ceiling of the house, especially for those who like beauty as an eye conditioner when looking at it.

Previously, we have seen various types of hanging ornaments that are usually in the same shape. What's interesting about this decoration is the rope used as the cover. Why rope? Because using rope as the main material is very easy to obtain, besides that it is not only utilizing new rope but used or unused rope can also be used. The prospects for business development in this industrial sector can be assessed from several aspects such as the availability of simple and easy-to-obtain raw materials, namely various types of ropes (stove axles, choir ropes, plastic ropes and wool ropes), public interest in crafts, profit and distribution. talent and creativity of students. In addition, the business objects to be produced also use materials that are rarely developed and unique. Moreover, for those who really like this type of handicraft, it will definitely be a special attraction for them and if this business is well practiced, the chances of success will be easily achieved. If viewed from the results of the people who are unemployed, it will not rule out the possibility to increase the workforce along with with the development of this type of craft.

\section{Literature Review}

\section{A. Development Prospects}

A person's creativity has no limits. Currently, there have been many business advances by relying on our creativity, whether it be in the culinary, fashion, and so on. This hanging decoration that we will create is a form of creativity by utilizing the basic material, namely rope. This decoration can also be made yourself because the manufacturing process has a low level of difficulty depending on how creative we are in making it. This Bohemian (Fringe Boho) Ceiling Decoration is perfect for decorating the ceiling of the house, especially for those who like beauty as an eye conditioner when looking at it.

Previously, we have seen various types of hanging ornaments that are usually in the same shape. What's interesting about this decoration is the rope used as the cover. Why rope? Because using rope as the main material is very easy to obtain, besides that it is not only utilizing new rope but used or unused rope can also be used. The prospects for business development in this industrial sector can be assessed from several aspects such as the availability of simple and easy-to-obtain raw materials, namely various types of ropes (stove axles, choir ropes, plastic ropes and wool ropes), public interest in crafts, profit and distribution. talent and creativity of students. In addition, the business objects to be produced also use materials that are rarely developed and unique. Moreover, for those who really like this type of handicraft, it will definitely be a special attraction for them and if this business is well practiced, the chances of success will be easily achieved. If viewed from the results of the people who are unemployed, it is possible to increase the workforce along with with the development of this type of craft.

\section{B. Business Economic Analysis}

In order to know the benefits that will be obtained in this business, then also the capital needed to open this business, we need an appropriate business analysis in order to achieve the desired goals. 
To streamline this program we use the SWOT analysis method, namely:

1.Strong (Strength)

In this hanging decoration business, we rely on our ability to cultivate creativity that can attract consumer interest. As can be seen by using rope as a basic material which turns out to have other uses besides being used as embroidery material.

2. Weakness (Weakness)

The weakness in this hanging decoration business is the availability of consumables such as ropes. The ropes we use are the stove and woll wicks.

3. Opportunity (Opportunity)

The opportunity we have to be able to compete in the market is that the products we create are innovations or new things in the city of Singkawang in general.

4. Threat (Threat)

The threat that may occur is the amount of competitiveness in the market because this decoration is still rarely found so that market opportunities are still guaranteed. What distinguishes only the power of creativity.

\section{Business Continuity}

If in this business process we get business results according to the target, then we will plan to further develop this business. In terms of variety of items, we will make more various forms and creativity. In fact, it is possible that we will use other basic materials that are still similar in function to ropes. Textile business wastes, such as rags and so on can be used and utilized to increase the variety of our products.

The greater the job opportunities for the unemployed that we will use in helping this business activity. The existing promotions will also be more intensively carried out to introduce our products, not only to the people around Singkawang, but also in other areas. In addition to affordable prices, the place also affects the business to be carried out and the place of business also supports the long-term sales process. The author also chooses a location in the Singkawang market area and can also market it online.

\section{Research Methods}

\section{A. Environmental Observations}

As the initial stage of establishing a business, what must be done is to make direct observations of the environment around us. The purpose of observing the surrounding environment is to look for business opportunities that can develop well in the future. From the observations in the surrounding environment, it was found that the people in the surrounding area were very fond of handicrafts, especially for decoration. This will very likely encourage the development of handicraft businesses, especially beautiful and unique decoration businesses. Therefore, we try to make a handicraft business made from rope as a beautiful hanging decoration.

\section{B. Making Business Planning}

The next step after getting the idea to set up a business is to make a business plan. In this business planning, it explains the business background, type of business, business location, marketing strategy for the schedule of activities, sources of funds, estimated costs required, revenue, and the benefits that will be obtained. In addition, it also includes a business feasibility analysis that will be carried out. 


\section{Marketing Strategy}

Marketing channels in the field of accessories crafts usually involve the following parties: producers, intermediaries, and end consumers or industrial users (Utomo: 2009). The following are some marketing strategies that will be carried out to support the success of the business, namely:

1. Make a bohemian style ceiling decoration (Fringe Boho) with various variations. This is intended to provide flexibility to consumers to be able to choose the shape they like.

2. Selling products at prices affordable to the community.

3. Distributing brochures containing the uniqueness, advantages and benefits of the product (bohemian-style ceiling decoration).

4. Offer products via online and also directly to colleagues or classmates. The business preparation referred to here is to prepare all the equipment needed to start a bohemian style ceiling decoration business (Fringe Boho), including how the promotional media will be used.

\section{Business Preparation}

The business preparation referred to here is to prepare all the equipment needed to start a bohemian style ceiling decoration business (Fringe Boho) including how the promotional media will be used.

\section{E. Starting a Business}

After all the preparations above have been done well, then this Bohemian Style Ceiling Decoration (Fringe Boho) business will begin. The implementation of this craft business program has a time-consuming manufacturing process.

\section{Results and Discussion}

\section{A. Budget}

Table 1. Summary of PKM-K Budget

\begin{tabular}{ccc}
\hline No. & Type of Expenditure & Biaya (Rp) \\
\hline $\mathbf{1}$ & Consumables & $\operatorname{Rp} 2.645 .000,00$ \\
$\mathbf{2}$ & Supporting Equipment & $\operatorname{Rp~} 1.771 .000,00$ \\
$\mathbf{3}$ & Etc & $\operatorname{Rp} 1.870 .000,00$ \\
\hline & Total & Rp $\mathbf{6 . 2 8 6 . 0 0 0 , 0 0}$ \\
\hline
\end{tabular}

\section{B. Schedule of Activities}

Table 2 PKM-K Activity Schedule

\begin{tabular}{|c|c|c|c|c|c|c|c|c|c|c|c|c|c|c|}
\hline \multirow[b]{2}{*}{ No } & \multirow[b]{2}{*}{ Details of activities } & \multicolumn{5}{|c|}{ October } & \multicolumn{4}{|c|}{ November } & \multicolumn{4}{|c|}{ December } \\
\hline & & 1 & 2 & 3 & 4 & 5 & 1 & 2 & 3 & 4 & 1 & 2 & 3 & 4 \\
\hline 1 & $\begin{array}{l}\text { Preparation of business } \\
\text { proposals }\end{array}$ & & & & & & & & & & & & & \\
\hline 2 & $\begin{array}{l}\text { Location survey and } \\
\text { raw materials }\end{array}$ & & & & & & & & & & & & & \\
\hline 3 & $\begin{array}{l}\text { Procurement of } \\
\text { equipment }\end{array}$ & & & & & & & & & & & & & \\
\hline 4 & $\begin{array}{l}\text { Procurement of } \\
\text { promotional media }\end{array}$ & & & & & & & & & & & & & \\
\hline 5 & Running a business & & & & & & & & & & & & & \\
\hline 6 & Product marketing & & & & & & & & & & & & & \\
\hline
\end{tabular}


Jurnal Terapan Manajemen dan Bisnis

Volume 6 Number 1March 2020. Page 1-7

e-ISSN: 2477-5282 p-ISSN: 2599-3127

C. Tools, Materials and Steps

Table 3 PKM-K Activity Schedule

\begin{tabular}{llll}
\hline NO. & TOOL & NO. & INGREDIENT \\
\hline 1 & Scissor & 1 & Cotton Rope \\
2 & Glue Shoot Tool & 2 & Wool \\
3 & Ruler & 3 & Rattan \\
4 & Marker & 4 & Chain \\
& & 5 & Glue Shoot \\
& & 6 & Pearl Ornament \\
& & 7 & Hook \\
\hline
\end{tabular}

The process of making a Bohemian ceiling decoration (Fringe Boho) is as follows:

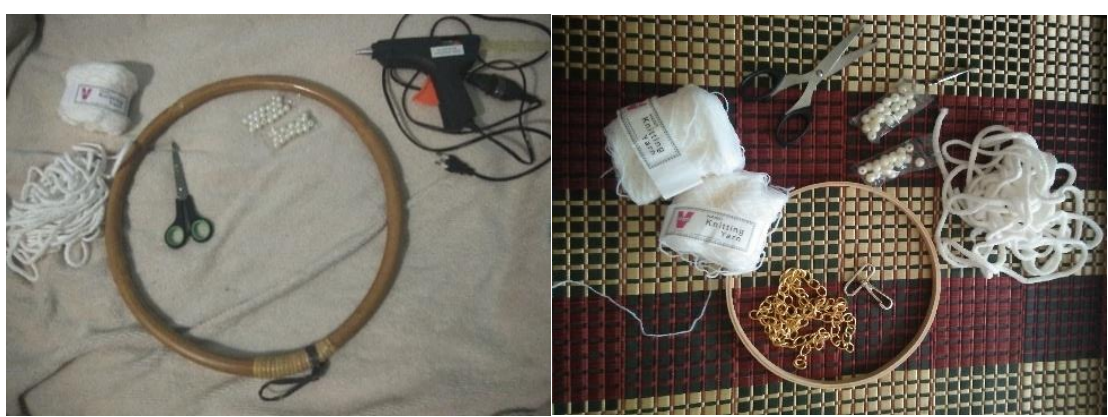

Figure 1 Tools and Materials

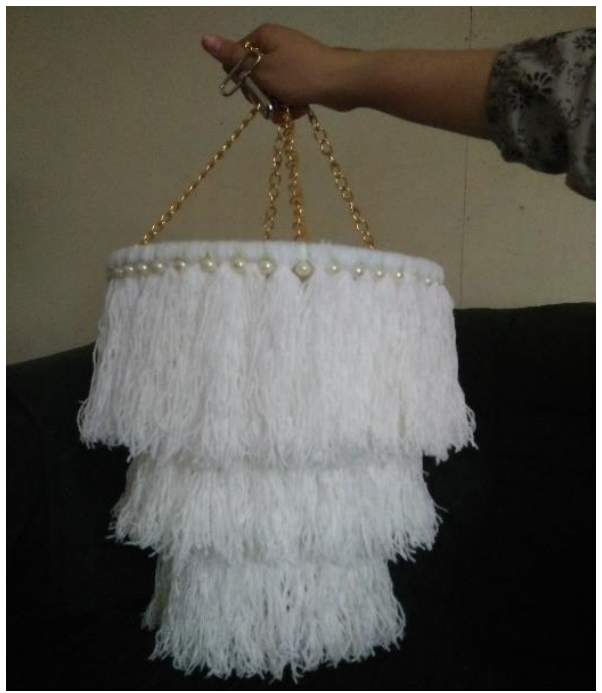

Figure 2 The Final Result of the Boho Fringe

1. Arrange the rattan into three or more parts (according to taste) from largest to smallest,

2. Measure parts of the rattan from largest to smallest with the same distance $(10 \mathrm{~cm})$.

3. After measuring, tie the rattan using cotton rope into one unit so that the rattan is in the form of a tunnel.

4. Measure the wool along $30 \mathrm{~cm}$, then arrange the wool and wrap the existing rattan and tie it.

5. Repeat the same for all parts of the rattan. 
6. When finished, then attach a chain on each side of the rattan.

7. Then attach each end of the chain to the hook.

8. Attach the pearl accessories on the desired side of the rattan.

9. Finally, hang the Bohemian Style (Fringe Boho) where you want it.

\section{Research Implication}

The country of Indonesia which has a wealth of cultural wealth in the world and this condition will certainly be an opportunity to take big risks and challenges for MSME players in Indonesia by taking advantage of existing conditions to carry out various variations of the best management for the economy, social and geographical in each region. (Sundiman, Chien, Andi, Surya, \& Asmara, 2019). SMEs will produce more innovations in business if they focus more on the knowledge group than innovation itself and how they are able to convey (transfer) this knowledge well which is then transformed into innovation in SMEs (Rumiyati \& Sundiman, 2017).

Entrepreneurship is someone who dares to be independent by giving up all resources or waste and effort, including knowledge of new products, determining production and marketing methods as well as fostering operating capital to produce a value of higher value. Nowadays, the Bohemian style is indeed being dominated by young people. Bring this style into the house to beautify the room. Simple, but attractive hanging decorations with cheap materials in an easy way to make and can be done yourself according to anywhere, such as internet social media. Therefore, as an initial step towards economic development in Indonesia, we must be able to make new innovations for a product that has minimal capital but can generate maximum profits.

\section{Conclusion}

This Bohemian Ceiling Decoration is a craft made from rope. The rope used can be various as desired, such as rope, wool rope, plastic rope, etc. But we are here using the basic material of wool rope. This handicraft business aims to increase creativity and be innovative in entrepreneurship, especially for young entrepreneurs.

With this program, it is hoped that we will be able to process creativity into a business opportunity that not only benefits ourselves, but also opens job opportunities for those who are unemployed. Our creativity in creating goods that are of high use value, interesting, and unique will be able to attract people to use our goods. With the hope that if this product can be realized and developed properly, we can create a business opportunity so that the unemployment rate in our country will decrease and indirectly we have helped the government.

\section{References}

Catheline \& Didi Sundiman. (2019). The Influence Of Ewom Through Instagram Social Media On Online Purchase Intention Of Products: Study In The City Of Batam. Jurnal Terapan Manajemen dan Bisnis Vol 5 Number 2.

Herlina, Yekti. 2003. Kreativitas dalam Seni Fotografi. Fakultas Seni dan Desain Universitas Kristen Petra. Vol. 5, No. 2, Juli 2003: 214 - 228.

Rumiyati, \& Sundiman, D. (2017). No Title. Peran Manajemen Pengetahuan Pada Kapasitas Unovasi Usaha Kecil Dan Menengah (UKM) (Studi Pada UKM Di Kota Sampit), 2(2), 136- 148. 
Jurnal Terapan Manajemen dan Bisnis

Volume 6 Number 1March 2020. Page 1-7

e-ISSN: 2477-5282 p-ISSN: 2599-3127

Suparta, I Made. 2010. JENIS HIASAN TATAHAN BADE. Fakultas Seni Rupa dan Desain ISI Denpasar., Vol.8, No. 1,: $81-104$.

Utomo , Tri Joko. 2009. FUNGSI DAN PERAN BISNIS RITEL DALAM SALURAN PEMASARAN. The Function and the Role of Retail Business in Marketing Line. STIE Pelita Nusantara Semarang. Vol. 4 No. 1 Juni 2009 : $44-55$. 